\title{
THE VIEW OF THE HOLY THREE HIERARCHS ON CULTURE AND EDUCATION
}

\author{
$\dagger$ IRINEU \\ Archbishop of Alba Iulia
}

Abstract: The present study presents the interaction of the Three Holy Hierarchs: Basil the Great, Gregory the Theologian and John Chrysostom, spiritual patrons of theological education, with the values of the secular culture of their time, marked by the expression of antique Hellenism. Interweaving genius and holiness, the Great Hierarchs of the world in the golden age of Christian Church acquired wisely all that was good in their culture, thus becoming outstanding intellectuals and perfect men. Accomodating harmoniously Christian teachings to ancient philosophy, which actually played the role of "an educator and guide towards Christ", they can be referred to in different ways: Saint Basil - a teacher of the divine and human wisdom, Saint Gregory - an admirer of Christian and secular knowledge, and Saint John "the most Hellenic of all Christians". According to the original perspective of the Three Holy Hierarchs on the relation between ecclesia and universitas, we understand that the educational purpose consists of an optimal integration of man in the existing order, in society and in history. Assuming the educational model of the Three Teachers certainly leads to acquiring an inner balance and to living a life of holiness.

Keywords: education, morality, culture, youth

\section{Familiarised with the moral values of ancient philosophy}

The Three Holy Hierarchs, Basil the Great, Gregory the Theologian and John Chrysostom have been established by the Orthodox Church as spiritual patrons of theological education, as they inspire and impel us to pay attention to Christian values, and ,with discernment, equally to the values in secular culture. Their work had a strong impact in the process of selecting, receiving and assimilating pedagogical principles and other durable values of secular thinking by Christian culture. The way in which the 
Church Fathers and writers treated the issue of the relations between the two worlds - Christian and pagan - aroused great interest in the fourth century, called the golden century of the Christian Church ${ }^{1}$.

The confessors of the evangelical faith had to face the religious, philosophical and moral pressures in the Hellenistic world, in which Christ's Church was developing. However, Christians were not the only critics of their contemporary culture, but also a series of writers of the time, who did not accept passively, nor did they reject tacitly the mythology elaborated by ancient Greeks. On the contrary, they started to produce arguments which attempted to undermine some of the essential elements of Greek philosophy and of other religious practices. It was necessary to have a delimitation between the perspective of Christian authors and that of the ancient philosophers on the axiological knowledge of life and it was also necessary to have a selection of ethical teachings in secular writings, as well as the constant limit between value and relativity ${ }^{2}$.

Saints Basil, Gregory and John lived in a world with this kind of cultural and religious heritage, full of doubt and confusion. Assimilating wisely everything that was good in the culture of their time, the Great Hierarchs and Ecumenical Teachers interwove genius and holiness, becoming outstanding intellectuals and perfect men. They did not show any reserve in having contacts with the philosophy of the ancient world, which,

\footnotetext{
1 "After assimilating the fundamental teachings of the ancient culture in the great pagan university centres, many former advocates or followers of the classical pagan culture decided to become members of the mystical Body of Christ, becoming landmarks in Christian theology, as it is the case of the Holy Fathers of the golden century" (Marius-Constantin Pavel, Educaţia creştină şi perceptele învăţăturii clasice in concepţia Sfântului Vasile cel Mare, in "Almanah bisericesc", Târgovişte, 2010, p. 380).

2 While secular education has prepared people for this existence, religious education has aimed at acquiring virtue and perfection, as steps leading to salvation.
} 
actually had the role of an "educator and guide towards Christ" 3 At the same time, they did not speak highly of it, in an exaggerate way, as the true philosophy leading to eternal life is the Holy Gospel, which comprises the plenary truth, revealed in a natural way by Christ - God Incarnate. They behave as authentic philosophers when they rebut wrong teachings, when they explain the consequences of an affirmation and when they describe a truth. Nevertheless, this philosophy does not drive them away from Christian faith, because forever and everywhere they are orators who remain near the young or the elderly, who know the manner of talking to them and guiding them ${ }^{4}$.

Saints Basil and Gregory studied in Caesarea in Cappadocia and in Athens, and Saint John Chrysostom studied in Antioch. They loved both the school and the church, becoming models for Christian students and astounding all through their excellent moral conduct. They blended harmoniously the ideal of Hellenic culture - Kalokagathia - that is, the perfect union between good and beauty, to the ideal of Christian thinking Filokalia - in other words, the love for the spiritual and saving beauty. These bright stars of Orthodoxy revealed to us that whereas the wise men of pagan antiquity regarded earthly life as a sphere of practising virtues, but also of pleasures, in order to acquire earthly happiness, Christian teachings consider earthly life as a fighting arena in order to acquire the blessed eternity ${ }^{5}$.

\footnotetext{
${ }^{3}$ Rev. Fr. Dumitru Popescu, PhD, Iisus Hristos Pantocrator, Publishing House IBMBOR, București, 2005, p. 191.

${ }^{4}$ The Holy Three Hierarchs are models for the teachers today, who must know that "each school subject should constitute a field of knowledge adapted in a pedagogical way, as well as a way of knowing" (Prof. Constantin Cucoş, $\mathrm{PhD}$, Specificul orei de religie în sistemul de învăţământ românesc, in "Almanah bisericesc", Târgovişte, 2010, p. 362).

${ }^{5}$ Here we mention Tertullian and Blessed Augustine, who regarded classical culture as a rival of Christian revelation and also the specifications in Apostolic Didascalia, which aim at counter-balancing secular culture with the moral, literary and historical values of the Holy Scripture.
} 


\section{Saint Basil the Great, teacher of the divine and human wisdom}

Saint Basil the Great acquired a vast secular culture during his studies, as well as afterwards. Therefore, as concerns Hellenic culture, he appears as a broad-minded man, endowed with great insight. He shows no reticence to contacts with pagans, moreover, discovering the treasures of ancient culture, he assimilated knowledge of history, philosophy and even rhetoric, which he practised for a certain period of time. All these remained familiar to him his entire life and influenced his exposition manner and his style $^{6}$. Familiarised with Plato's writings and with those of the Stoic philosophers, he put these to the use of Christian teachings. Admirer of Greek thinking, he borrowed a great deal from classical authors, uniting very ingeniously their literature to the Holy Scripture. Thus, Saint Gregory of Nyssa refers to Saint Basil in the following words: "He instructed everyone in both divine and secular wisdom. As a brave, experienced man armed against adversaries with every kind of training, he defeated them through both disciplines" 7 .

In his great dogmatic treatises and in his speeches held in front of people, which were genuine treatises of general knowledge, Saint Basil sometimes integrated elements from ancient philosophy. In his famous Hexaemeron ${ }^{8}$, or the commentary of the six days of creation, one can find, if not an

6 Hans Freiherr von Campenhausen, Părinţii greci ai Bisericii, coll. "Înţelepciune şi credinţă", translated by Maria-Magdalena Anghelescu, Humanitas Publishing House, Bucureşti, 2005, p. 130-131.

${ }^{7}$ Saint Gregory of Nyssa, In Laudem Fratris Basilii, in Migne, P.G. vol. XLVI, col. 790 C; see also Vasile Prescure, Profilul moral al Sf. Vasile cel Mare, in, "Studii Teologice",year XIV, 1962, nr. 5-6, p. 286.

8 Saint Basil the Great, Omilii la Hexaemeron (On the Hexaemeron), translation and notes by Fr. Dumitru Fecioru, Sophia Publishing House, Bucureşti, 2004, p. 219. 
enyclopedia of the knowledge of his time, at least a sum of the scientific knowledge the Cappadocian hierarch possessed, knowledge which extended beyond theology. In an elegant style, doubled by a temperate tone, Saint Basil the Great offers a real programme for studying the Greek language, which was necesary for the young men in general, as well as for theologians, in order to approach the Church writings and certainly, the Holy Scripture, in a mature, not in a dilettant way. In order to understand the Word of God it is necessary to practise handling the weapons of secular culture. He affirms: "we first accustom ourselves to the sun's reflection in the water, and then become able to turn our eyes upon the very sun itself"' . Hence, he gives us to understand that in the same way, we, using secular teachings, will be able to understand Christian teachings with increased objectivity.

Saint Basil the Great offers us a real programme for studying the Greek literature. Addressing young men, the wise hierarch shows that a young man thirsty for culture ought to turn preferably towards the works that celebrate virtue. The writings of great ancient Greek writers such as Hesiod, Homer, Solon and Theognis do nothing but urge the soul, that is at the age of great expectations, to assume and practise virtue, regarded by the Cappadocian hierarch as the only good that is not lost after death, as a goal of man's aspirations. "Almost all who have written upon the subject of wisdom have more or less, in proportion to their several abilities, extolled virtue in their writings. Such men must one obey, and must try to realize their words in his life" ${ }^{10}$. Among pagan works, young people should not read only the books referring to virtue, but to imitate the bee, which visits flowers and collects the clean and useful nectar, leaving the rest. "So we, if wise, shall take from heathen books whatever befits us and is

${ }^{9}$ Idem, Omilia a XXII-a către tineri (Address to young men), in "Omilii şi cuvântări", translation and notes by Dumitru Fecioru, Basilica Publishing House, Bucureşti, 2009, p. 323.

${ }^{10}$ Ibidem, p. 329. 
allied to the truth, and shall pass over the rest. And just as in culling roses we avoid the thorns, from such writings as these we will gather everything useful, and guard against the noxious" ${ }^{11}$.

According to Saint Basil, the selection of various nonChristian authors should be made taking into account the extent in which they praise virtue and condemn viciousness, but particularly when their work is reinforced by their example. The work of Saint Basil is animated by a Christian spirit. He shows that many books of secular thinking present some principles and actions in accordance with the teachings of the Holy Gospel, which young people should know. Saint Basil offers the example of Pericles, who suffered for a whole day the insults of a citizen without reacting, then the case of Euclid of Megara, threatened with death, who made a vow to forgive the aggressor - examples that reflect the anticipation of Christ's teaching to suffer persecution and forgive (according to Mt. 5,44). He also presents the case of Socrates the philosopher, who was hit in the face by a drunkard, but did not respond, just as the Saviour says that if someone smites you on the cheek you should turn the other. Saint Basil supports the idea of imitating the teachings that belong to classical authors when the latter do not show a deceitful behaviour, such as the model of scribes and Pharisees in the Scripture, and when their work is reinforced by the very example of their lives. He suggests, as a strict criterion of selection, the interpenetration of the two aspects, "For he, who by his works exemplifies the wisdom which with others is a matter of theory alone, breathes; all others flutter about like shadows" ${ }^{12}$.

${ }_{11}$ Ibidem, p. 325.

12 Ibidem, p. 329. 


\section{Saint Gregory the Theologian, admirer of Christian and secular erudition}

Saint Gregory the Theologian is the wise hierarch who accomplished the interweaving of Hellenism and Christianity in the superlative, in the most marvellous way. Endowed with an extraordinary analytical capacity, with an erudition competing easily with the genius of Pindar, he condemned in his writings the position of Emperor Julian the Apostate. Follower of the oriental cult of Mithras, the emperor persecuted Christianity in favour of a form of religious syncretism, based on degenerative elements of Neoplatonism, such as magic and theurgy. The great theologian attacked vehemently "the law against Christian teachers", promulgated by the emperor in June $13^{\text {th }}, 362$, in order to drive Christians away from the study of secular literature. He wanted teachers to renounce the interpretation of classical authors in their lessons and Christian students were forbidden to attend pagan schools. Saint Gregory considered that the emperor deserved to be abhorred, as he had turned "this injustice" 13 into a law and defended Christians' right to study and teach Greek culture in schools. Replying to the emperor, he wrote: "Only you have got the right to Hellenism? Does Hellenism come from you?"14. One must also mention that despite such restrictions, Christian teachers, who in general were seriously prepared, continued to make references to classical authors.

Saint Gregory had a great admiration for Greek culture, considering it very useful. This is the reason why he defended it

\footnotetext{
13 Saint Gregory of Nazianzus, De profesoribus, apud Cezar Vasiliu, PhD, Atitudinea Sfinţilor Trei Ierarhi faţă de societatea vremii lor, in "Studii Teologice", Year XXXII, nr. 1-2, January-February 1980, p. 51; see also Sozomen, Istoria bisericească, III, 16, translated by Metropolitan Iosif Gheorghian, Bucureşti, 1899, p. 182-183.

${ }^{14}$ Idem, Discursul IV, Despre Impăratul Iulian (Discourse IV, On Emperor Julian), apud Cezar Vasiliu, $\mathrm{PhD}$, quoted article, p. 58-59.
} 
from attacks coming from Christians themselves. In his funeral oration on Saint Basil he said: "I take it as admitted by men of sense, that the first of our advantages is education (our note culture); and not only this our more noble form of it, which disregards rhetorical ornaments and glory, and holds to salvation, and beauty in the objects of our contemplation: but even that external culture (our note - secular) which many Christians illjudgingly abhor, as treacherous and dangerous, and keeping us afar from God. For as we ought not to neglect the heavens, and earth, and air, and all such things, because some have wrongly seized upon them. We must not then dishonour education, because some men are pleased to do so, but rather suppose such men to be boorish and uneducated, desiring all men to be as they themselves are, in order to hide themselves in the general, and escape the detection of their want of culture" ${ }^{15}$. According to the great theologian, culture has a purifying role, it elevates and ennobles us, leading us on the way to self-improvement, constantly appeasing our thirst for spiritual perfection. Culture is acquired through the contact with school, with scholars and with books.

Saint Gregory spent a great deal of time with his friend, Saint Basil the Great, praying together and debating subjects from the field of philosophy and Christian religion. In the ancient citadel of Theseus, the golden Athens, young Gregory and Basil had renowned teachers such as Himerios and Proheresios. As for the subjects studied by the two, these were eloquence or oratory art, philosophy, dialectic and grammar ${ }^{16}$. Therefore, they approach

${ }^{15}$ Saint Gregory of Nazianzus, Apologia şi elogiul Sfântului Vasile cel Mare (Apology and Eulogy to Saint Basil the Great), translated by N. Donos, Huşi, 1931, p. 128; see also Saint Gregory the Theologian, Panegiric in cinstea Sfântului Vasile cel Mare (Panegyric on Saint Basil), traslation, introd. and notes by Ioana Costa, IBMO Publishing House, București, 2014, p. 22.

16 Rev. Fr. Ioan G. Coman, $\mathrm{PhD}$, Studiile universitare ale Părinţilor capadocieni(The University Studies of Cappadocian Fathers ), in "Frumuseţile iubirii de oameni în spiritualitatea patristică"(The beauties of loving people in 
the relations between Christianity and Hellenism in a similar way. Indeed, Saint Gregory was greatly influenced by ancient Greek culture, which was of use to him in systematising the dogmas of the Church in such an impressive way as to receive the name the Theologian. It was again Greek culture, with its means of expression and its beautiful writing, which he used, that helped him acquire a delicate sense of modelling the word, making himself wanted among the rhetors of the Athenian Academy. Greek culture offered Saint Gregory an extremely prolific poetic inspiration, as he wrote almost 16000 verses, which can be compared to those of Homer, Pindar, Sophocles and Vergil through the exquisite vocabulary, the gracefulness of the verse and the harmony of the rhythm ${ }^{17}$.

Although he had reserves to secular culture, from a moral and religious point of view, Saint Gregory highlighted the role of the art of dicourse, considering it necessary for preaching the truth of faith. The illustrious theologian and preacher wrote: "Our most cherished studies were not the most pleasant, but the most excellent; this being one means of forming young minds in a virtuous or vicious mould. Two ways were known to us, the first of greater value, the second of smaller consequence: the one leading to our sacred buildings and the teachers there, the other to secular instructors. All others we left to those who would pursue them - to feasts, theatres, meetings, banquets. For nothing is in my opinion of value, save that which leads to virtue and to the improvement of its devotees. Different men have different names, derived from their fathers, their families, their pursuits, their exploits: we had but one great business and name - to be and to

patristic spirituality) , Mitropolia Banatului Publishing House, Timişoara, 1988, p. 119-120.

${ }^{17}$ Idem, Geniul Sfântului Grigorie de Nazianz (The genius of Saint Gregory of Nazianzus), in "Studii Teologice", nr. 4-6, July-December, 1994, p. 31; see also Michele Pellegrino, La poesia d S. Grigorio Nazianzeno, Milano, 1932, p. 7778. 
be called Christians" 18 . Here he refers to Saint Basil, "the great value of his century", who was in Athens "a companion in his studies, in his room and with his advice" ${ }^{19}$.

\section{Saint John Chrysostom, "the most Hellenic of all Christians"}

It is said and believed that Saint John Chrysostom did not esteem Greek culture to the same extent as Saints Basil and Gregory. Some researchers even came to prove that Saint John would have showed disdain for the cultural creations of the ancient world and the famous Greek philosophers, starting with Plato. Such opinions are wrong, knowing that Saint John wrote in the ancient Greek language. In the treatise On the Priesthood, he confesses that he partook of Hellenistic culture "with eagerness and zeal" ${ }^{\prime 2}$. Just like the two other hierarchs, Saint John Chrysostom is motivated by the same noble desire to illuminate his soul, from an intercultural perspective. Born in Syria, he gave the Greek language the highest power of expression and refinement, so that he was called Chrysostomos ("Golden Mouth"). This would not have been possible without his ambition to be exquisite in his academic studies, in the field of law, philosophy and rhetoric, embellishing his ideational richness and the vast semantic possibilities of the Greek language. Thus, he was considered "the most Hellenic of all Christians" ${ }^{21}$.

\footnotetext{
${ }^{18}$ Saint Gregory of Nazianzus, Apologia şi elogiul Sfântului Vasile cel Mare... (Apology and Eulogy to Saint Basil the Great), p. 139-140.

${ }^{19}$ Idem, Despre viaţa sa (On his life), 25-26, P.G. 37, col. 1044.

20 Saint John Chrysostom, Tratatul despre preoţie (On the Priesthood), translation by Dumitru Fecioru, Sophia Publishing House, București, 2004, p. 30 .

${ }^{21}$ Demetrios J. Constantelos, John Chrysostom's Greek Classical Education and its Importance to Us Today, in "Greek Orthodox Theological Review", vol. 36, nr. 2, 1991, p. 110.
} 
Although he did not study in Athens, where Saint Basil the Great and Saint Gregory the Theologian had studied, we understand that the great Antiochian did not lack enthusiasm for the Greek culture. If he had really disdained ancient culture, the affirmation that he was the greatest orator after Demosthenes ${ }^{22}$ would not be justified. Benefitting from a solid classical culture was the very reason why Saint John could express himself grammatically correct in a unique and praiseworthy way. His admiration for the classical culture was shown in that in his works he accepted Homer, Sophocles, Euripides, Aristophanes, Demosthenes, Thucydides, Pindar and the philosophers Zeno, Socrates, Plato, Aristotle, Pythagoras and Diogenes $^{23}$. Hence, we can conclude that he accumulated much knowledge and profound wisdom from Hellenistic culture.

Saint John Chrysostom polarises man's fundamental problem in the access to education and its assimilation. While he did not share Plato's conception on man, he took over the concept of ritmizo, used by the philosopher to express the notion of education, understanding it as the whole process of integration in the rhythm of the harmony of human and universal laws. "There is a Greek conception, through the postulate of education as a harmonious work, but there is also a Christian conception, through man's soteriological postulate, as a way of ascension towards the initial beauty of God's image" ${ }^{24}$. The ideal of education has a profound religious dimension, as it refers to the cultivation of faith and the separation from ephemeral goods, the child being suggested a moral and intelligent way of life, directed towards his

${ }^{22}$ Liviu Petcu, Personalitatea Sfântului Ioan Gură de Aur (The personality of Saint John Chrysostom), in "Altarul Reîntregirii", nr. 2, 2008, p. 261, 263.

23 Archdecon Constantin Voicu, PhD, Sfinţii Trei Ierarhi - îndemnători la cultură, in “Telegraful Român”, Year 160, nr. 1-4, 1-15 January, 2012, p. 8.

${ }^{24}$ Cezar Vasiliu, $\mathrm{PhD}$, Atitudinea Sfinţilor Trei Ierarhi faţă de societatea vremii lor ..., p. 60-61. 
spiritual fulfillment, in harmony with his fellows, with nature and with God.

In the view of Saint John Chrysostom, education represents man's capital problem, all possible evils resulting from the lack of education. A child lacking education is considered an enemy of all, of God, of nature, of laws and of social life. "For as untilled land, such is also youth neglected, bringing forth many thorns from many quarters. Let us then send forth on them the fire of the Spirit, and burn up these wicked desires, and let us break up our fields, and make them ready for the reception of the seed, and the young men among us let us exhibit with soberer minds than the old elsewhere". The ideal of education has a profound dimension because it aims at cultivating faith and at despising ephemeral goods. "Education - Chrysostom suggests - means taking care of children and young people as concerns their soul's purity and decency, bringing up the child morally, correctly, a righteous man, bringing him up in devoutness, taking care of his soul, modeling his intelligence, forming an athlete for Christ, in short, taking care of his soul's salvation" 25 .

Education is similar to an art; there is no greater art than education, because if all arts bring something useful for this world, the art of education is done in order to have access to the afterworld. Essentially, the education of children is the foundation, the training and the order of the whole world, our entire existence depending on it. Parents have the main role in education and they should follow the example of painters and sculptors. "Like the creators of statues - Saint John Chrysostom advises us - do you give all your leisure to fashioning these wondrous statues of God. And, as you remove what is superfluous and add what is lacking, inspect them day by day, to see what

25 Saint John Chrysostom, Omilii la Matei, omilia XLIX, V, (Homilies on Matthew, Homily XLIX, $V$ ) in col. PSB, vol. 23, IBMBOR Publishing House, București, 1994, p. 576-577. 
good qualities nature has supplied so that you will increase them, and what faults so that you eradicate them"26.

\section{Secular and religious values; their complementarity and moralising role}

The Holy Three Hierarchs, great teachers of the Eastern Church, instruct us to love culture and good science, fighting against ignorance and obscurantism. From them we receive an impetus to oppose those who, in the name of Christ, spread false doctrines and cultivate the darkness of thinking. The Holy Three Hierarchs, enriched in grace and knowledge, indicated with great accuracy the conduct that the Church must adopt towards the culture of their time and towards the culture of all times. It is obvious for us that they had a positive attitude towards ancient culture, accepting and using all the precious elements in it ${ }^{27}$.

The great hierarchs of the Orthodox Church drew on the conception of Saints Basil, Gregory and John as concerns the relation between the Church and culture. Hence, they never disregarded culture or oppressed scientists. Despite grievous circumstances and many difficulties, the Church, following the example of patience and diligence of its divine Founder, proved to be a creator of spiritual values, and the hierarchs and its consecrated servants have contributed not only to the moral progress, but also to the cultural progress. Through the power given to it by the Gospel, culture has proved to be a means of

${ }^{26}$ Idem, Despre feciorie. Apologia vieţii monahale. Despre creşterea copiilor (On chastity. The apology of monastic life. On raising children), IBMBOR Publishing House, Bucureşti, 2001, p. 53.

${ }^{27}$ As early as the second century, Clement of Alexandria, who in general had a moderate attitude, tried to show the profound relation between Greek philosophy and Christian doctrine, confessing that "this relation is not one of enmity, but one of friendship", (according to Fr. Ioan G. Coman, Patrologia, Sfânta Mănăstire Dervent Publishing House, 1999, p. 69). 
transfiguration of our world, making efficient all the forms of positive creative manifestation of $\operatorname{man}^{28}$.

In modern society, characterising an education system as being secular or religious can no longer and should no longer be a reason for the separation of educational values. The values promoted by secular sciences are not a synonym for evil. The spiritual and material values promoted through modern education must complement, not eliminate each other. It is not the degree of secularism or religiosity that determines the value of education, but man's degree of spiritualisation, which ought to be ensured through educational programmes. A genuine education must conjugate and complement the two categories of values in the perspective of culturalising, spiritualising and perfecting the human being ${ }^{29}$.

In the Eastern Orthodox Church there are many examples of learned hierarchs, who cherished science and culture, being on the line of Saints Basil, Gregory and John. As we advance in time, we witness an evolution of culture and we benefit from its fruits. At the same time, we become aware of the necessity of culture in order to raise the level of our theological studies and to bring these in accordance with the need of our religious life in contemporary society. It is in this context that we must include teaching religion classes in schools, in order to promote moral

\footnotetext{
28 "The continuous renewal and overcoming oneself constitute the dynamics of evangelical Christianity" $(\dagger$ Anastasios Yannoulatos, Ortodoxia şi problemele lumii contemporane (Orthodoxy and the issues of contemporary world), translated by Gabriel Mândrilă, PhD candidate and Fr. Constantin Coman, PhD, Bizantină Publishing House, Bucureşti, 2003, p. 117).

29 Religious education is connected to esthetic, moral and civic education, which it reinforces and out of which it extracts, sequentially, some premises and foundations.
} 
principles, evangelical humanism and a decent conduct. The absence of Christian culture leads to secularism ${ }^{30}$.

The Holy Three Hierarchs gave their entire attention to make sure that life in Christ and in Church should have spiritual coherence. They had a lot of expertise, as they were formed through the encounter of Church and school, between ecclesia and universitas. Respecting culture, the cleric and the theologian must treasure the knowledge that leads to salvation and transmit it to others as well. Therefore, today's theological education must be based, besides the subjects pertaining to theology, on elements of general knowledge, especially on exact sciences, knowledge of classical and modern languages and literature and on the initiation in different branches of philosophy, according to the model offered by the Holy Three Hierarchs. They teach us that the educational purpose consists an optimal integration of man in the existing order, in society and in history. There is no greater occupation than educating and forming young people ${ }^{31}$.

Young people today, within range of contradictory trends coming from Western Europe, as well as from the Euro-Asian syncretism, are in the situation of adopting sua sponte a certain attitude towards Christianity. In this situation, all those who dedicate themselves to educating children and young people are called to make these aware of the dangers of "the spirit of our time", which are present everywhere, both morally and socially. They also have the mission to offer them righteous judgment, to teach and advise them to use the power of discerning things according to the model of the Three Holy Hierarchs, in other

30 Through its very nature and definition, the so-called secularism is a movement of ideas and habits which promotes a humanism which completely disregards God.

31 The educator Jan Amos Comenius wondered rhetorically and gave the answer: "Is there a greater gift we can offer society than teaching and cultivating young people?”. (Didactica Magna, Didactică şi Pedagogică Publishing House, Bucureşti, 1980, p. 7). 
words, to be guides in acquiring the inner balance and the true life. Saints Basil, Gregory and John, bright stars of the universal Church, convey to us that education is a difficult art which is accomplished for the sake of moralizing and perfecting human personality $^{32}$.

1. Campenhausen, Hans Freiherr von, Părinţ̧ii greci ai Bisericii, coll. "Înțelepciune şi credinţă", translated by Maria-Magdalena Anghelescu, Humanitas Publishing House, Bucureşti, 2005.

2. Coman, Fr. Ioan G., Patrologia, Sfânta Mănăstire Dervent Publishing House, 1999.

3. Idem, Studiile universitare ale Părintilor capadocieni(The University Studies of Cappadocian Fathers ), in "Frumuseţile iubirii de oameni în spiritualitatea patristică"(The beauties of loving people in patristic spirituality) , Mitropolia Banatului Publishing House, Timişoara, 1988.

4. Idem, Geniul Sfântului Grigorie de Nazianz (The genius of Saint Gregory of Nazianzus), in "Studii Teologice", nr. 4-6, July-December, 1994, p. 31; see also Michele Pellegrino, La poesia d S. Grigorio Nazianzeno, Milano, 1932.

5. Constantelos, Demetrios J., John Chrysostom's Greek Classical Education and its Importance to Us Today, in "Greek Orthodox Theological Review", vol. 36, nr. 2, 1991.

6. Cucoş, Prof. Constantin, $\mathrm{PhD}$, Specificul orei de religie în sistemul de invătătânât românesc, in "Almanah bisericesc", Târgovişte, 2010.

7. Pavel, Marius-Constantin, Educaţia creştină şi perceptele invătăturii clasice în conceptia Sfântului Vasile cel Mare, in "Almanah bisericesc", Târgovişte, 2010.

8. Petcu, Liviu, Personalitatea Sfântului Ioan Gură de Aur (The personality of Saint John Chrysostom), in "Altarul Reîntregirii", nr. 2, 2008.

9. Popescu, Rev. Fr. Dumitru, PhD, Iisus Hristos Pantocrator, Publishing House IBMBOR, Bucureşti, 2005.

${ }^{32}$ Saint John Chrysostom wrote: "For what is equal to training the soul, and forming the mind of one that is young? For he that has this art, ought to be more exactly observant than any painter and any sculptor". (Omilii la Matei, omilia LIX, VII - Homilies on Matthew, Homily LIX, VII, in col. PSB, vol. 23, p. 695). 
10. Prescure, Vasile, Profilul moral al Sf. Vasile cel Mare, in "Studii Teologice",year XIV, 1962, nr. 5-6.

11. Saint Basil the Great, Omilia a XXII-a către tineri (Address to young men), in "Omilii şi cuvântări", translation and notes by Dumitru Fecioru, Basilica Publishing House, Bucureşti, 2009.

12. Idem, Omilii la Hexaemeron (On the Hexaemeron), translation and notes by Fr. Dumitru Fecioru, Sophia Publishing House, Bucureşti, 2004.

13. Saint Gregory of Nyssa, In Laudem Fratris Basilii, in Migne, P.G. vol. XLVI, col. 790 C.

14. Saint Gregory of Nazianzus, Apologia şi elogiul Sfântului Vasile cel Mare (Apology and Eulogy to Saint Basil the Great), translated by N. Donos, Huşi, 1931.

15. Saint Gregory the Theologian, Panegiric în cinstea Sfântului Vasile cel Mare (Panegyric on Saint Basil), traslation, introd. and notes by Ioana Costa, IBMO Publishing House, București, 2014.

16. Saint John Chrysostom, Despre feciorie. Apologia vieții monahale. Despre creşterea copiilor (On chastity. The apology of monastic life. On raising children), IBMBOR Publishing House, Bucureşti, 2001.

17. Idem, Omilii la Matei, omilia LIX, VII - Homilies on Matthew, Homily $L I X$, VII, in col. PSB, vol. 23.

18. Idem, Omilii la Matei, omilia XLIX, V, (Homilies on Matthew, Homily $X L I X, V)$ in col. PSB, vol. 23, IBMBOR Publishing House, București, 1994.

19. Idem, Tratatul despre preoţie (On the Priesthood), translation by Dumitru Fecioru, Sophia Publishing House, București, 2004.

20. Sozomen, Istoria bisericească, III, 16, translated by Metropolitan Iosif Gheorghian, Bucureşti, 1899.

21. Vasiliu, Cezar, PhD, Atitudinea Sfinţilor Trei Ierarhi faţă de societatea vremii lor, in "Studii Teologice", Year XXXII, nr. 1-2, January-February 1980.

22. Voicu, Archdecon Constantin, PhD, Sfinţii Trei Ierarhi - îndemnători la cultură, in "Telegraful Român", Year 160, nr. 1-4, 1-15 January, 2012.

23. Yannoulatos, †Anastasios, Ortodoxia şi problemele lumii contemporane (Orthodoxy and the issues of contemporary world), translated by Gabriel Mândrilă, PhD candidate and Fr. Constantin Coman, PhD, Bizantină Publishing House, Bucureşti, 2003. 